\title{
Work Intention as Mediator in the Relationship between Work Passion and Organizational Commitment among Teachers in Malaysia
}

\author{
Amalina Ibrahim, Wan Shahrazad Wan Sulaiman, Fatimah Wati Halim
}

\begin{abstract}
Organizational commitment among employees is important to determine organizational effectiveness as employees with higher organizational commitment have higher motivation to stay with their organization. In recent years, previous studies have shown that the teachers' organizational commitment are low and moderate. Therefore, this study focuses on the effect of work passion toward organizational commitment with work intention as the mediator. The objectives of this study was to determine the effect of work passion on work intention and organizational commitment among teachers and to determine the role of work intention as a mediator in the effect of work passion on organizational commitment among teachers. This study employed a cross-sectional survey involving 355 school teachers in Malaysia through multi-stage cluster sampling technique. Data were analyzed using descriptive analysis, while confirmatory factor analysis (CFA) and structural equation modeling (SEM) were used to determine the fitness of the model with the data. Findings showed that organizational commitment and work passion among school teachers were moderate, while work intention was at a higher level. SEM analysis showed that the model has a good fit with CMIN/df=3.22, GFI $=0.95$, CFI=0.97, TLI=0.95, RMSEA=0.08. In addition, job factors have a significant direct effect on work intention and organizational commitment. Results also showed that work intention mediated the relationship between work passion and organizational commitment. The results of this imply the importance of work passion and work intention in enhancing organizational commitment among teachers in Malaysia.
\end{abstract}

Index Terms: work passion, work intention, organizational commitment, teachers.

\section{INTRODUCTION}

The education system in Malaysia has experienced various changes throughout the decade and success of the education system largely depends on the collaboration of educators, especially teachers. According to Minister of Education Malaysia, the government is committed to transform the education system to equip human resources with the 21st century knowledge and skills in order to become the best global competitor [1]. Hence, educational institutions especially schools aimed to have committed teachers in their system [2]. However, the implementation of changes in the education system has influenced work situations such as organizational commitment, job stress, motivation, passion and job satisfaction [3]. These changes indicate that organizational commitment among teachers is very necessary, thus, Ibrahim, Halim and Sulaiman stated that committed teachers can contribute to organizational achievement, indirectly providing a good image to various parties including organizations and ministry [4].

Undoubtedly the role of teachers nowadays is more challenging. Bajunid believes that there are differences in teachers' commitment in the past compared to now due to the current situation and value system [5]. The National Union of the Teaching Profession Malaysia reported that $70 \%$ from 9000 teachers in Malaysia face job stress caused by workload and the responsibility to deal with employers, clerks, peers, parents and students [6]. Polly et al. also mentioned that teachers in Malaysia are burdened with trials and tribulations [7]. Hence, Halim stated that teaching profession is not an easy task, it requires a sense of responsibility born of a noble and sincere hearts [8]. If teachers have anxiety and anger, these attitudes will lead them to feel unacceptable in the organization or unwilling to contribute towards organizational commitment [8]. This may affect teachers' work passion, work intention and also organizational commitment.

Educators, including teachers have the responsibility to achieve educational effectiveness which is translated into the development of quality human capital. Halim and Rabindarang found that organizational commitment is a key factor in realizing the organizational aspirations where committed employees are regarded as human capital who become the pillar of a developed country [9] [3]. However, Abdullah, Sekong and Laji mentioned that the high workload experienced among teachers may affect organizational commitment [10]. Dee, Henkin and Singleton stated that organizational commitment among teachers is important to ascertain organizational effectiveness and it is crucial to identify the factors that can influence organizational commitment among teachers [11].

Organizational commitment refers to the psychological link between the employee and his or her organization that makes it less likely for the employee to leave the organization [12]. According to Meyer and Allen, organizational commitment is categorized into three components which is affective commitment, continuance commitment and normative commitment [13]. Past research has shown that there are several factors that can influence organizational commitment. For example, it can be influenced by leadership of principals or headmaster [14]; feedback, encouragement and appreciation by organization [15]; leadership supervising; organizational support such as motivating and helping teachers for professional development [16]; job satisfaction [17], and, personal factors [18]. Hence, Zigarmi et al. introduced work passion as an antecedent of organizational behavior [19].

Zigarmi et al. defined Employee Work Passion as an individual's persistent, emotionally positive, meaning-based state of well-being stemming from reoccurring cognitive and affective 
appraisals of various job and organizational situations, which results in consistent, constructive work intentions and behaviors [19]. On the other hand, Perrewe et al. define work passion as an individual's emotional and persistent state of desire on the basis of cognitive and affective work appraisals, which results in consistent work intentions and behaviors [20]. Vallerand et al. stated work passion as characteristically self-enhancing, thus becoming a stable feature of one's identity [21].

Nimon and Zigarmi found that there are three categories of work passion which act as factors of employee work passion [22]. The three factors consist of: (i) job experiences; (ii) organizational experiences; and (iii) experiences with people. However, in this research, the work passion factors are known as organizational factors, job factors and individual factors. Nimon and Zigarmi also clustered distributive justice, growth, performance expectations and procedural justice under organizational factors [22]. In addition, autonomy, meaningful work, task variety and well-being are clustered under job factors, and finally, individual factors consist of connectedness with colleagues, connectedness with leader, collaboration and feedback [22].

Intention has been shown to be a strong construct in the attitude-intention-behavior sequence [23]. It is proved by several models such as the theory of reasoned action [24] and the theory of planned behavior [25, 26] which explain the relationship between intention and behavior, and also the role of intention in predicting behavior [27]. Ajzen and Fishbein defined intention as a mental representation of a desired future [28]. Meanwhile, Zigarmi et al. defined it as a goal representation or schema, and means representations or schema, and is formed as a result of the appraisal process to meet needs stemming from a sense of, or lack of, the appraiser's well-being [23]. According to Zigarmi et al., work intention consists of intent to stay, intent to use organizational citizenship behavior (OCB), intent to use discretionary effort, intent to endorse and intent to perform [23]. Work passion factors may affect organizational commitment. Zigarmi et al. stated that intention is best understood as a guide for purposeful action because they are a mental representation of behavior an individual might or will use to cope with a high or low sense of well-being [23].

\section{LITERATURE REVIEW}

\section{A. Relationship between Work Passion and Organizational Commitment}

Work passion consists of organizational factors, job factors and individual factors. Nimon and Zigarmi clustered distributive justice, growth, performance expectations and procedural justice under organizational factors [22]. Tremblay et al. in their study found that when an employee is given a fair procedure, it can increase organizational commitment because employees feel they have gained equality as one of the members of the organization [29]. Besides that, Haar et al. explained that if justice does not occur in the organization, it tends to give a negative impression, especially to employees and organizations, such as reducing employee performance, increasing turnover, and reducing organizational commitment [30]. Rahman et al. in their study on 500 educators in Pakistan found that procedural justice and distributive justice are both worthy and both have positive impacts on organizational commitment [31].

Daud reported that growth plays an important role to organizational commitment, where most of the respondents in the interview session mentioned that appreciation, recognition and reward for employee contributions can increase commitment to the organization [32]. Weng et al. in their survey also found that growth has a positive relationship with organizational commitment among workers in China, in which their study was focused on how growth can be used in managing organizational commitment [33]. Barbier et al. mentioned that performance expectation may contribute to positive effect, where it drives employees to increase their work effort and achieve organizational expectation [34]. This also can contribute to improve organizational commitment among employees.

Autonomy, meaningful work, task variety and workload balance are clustered under job factors. Wrzesniewski et al. stated that individuals who have a meaningful work are more likely to see their work as a career but also focus on organizational development [35]. Geldenhuys, Taba and Venter in their study on 415 workers in South Africa found that meaningful work has a significant effect on organizational commitment [36]. When employees obtain meaningful work, it will indirectly increase organizational commitment. Ozturk mentioned that autonomy, feedback and task variety can influence and help employees monitor their behavior which is also expressed as a sense of personal control as well as a sense of responsibility [37]. When employees have a sense of responsibility, they tend to help their organizations and perform well.

Eby et al. also found that autonomy and feedback have a positive relationship with affective commitment [38]. Huang and Hsiao mentioned that job factors are strong predictors towards affective component [39]. Their study was also supported by Liu and Norcio who found that job factors have significant relationship with affective component [40]. Apart from that, Lee and Ashforth concluded that emotions, workload, lack of autonomy and intent to turnover may decrease organizational commitment among workers [41]. Dewe stated that workload is a common stress in 
workplace [42]. These results were consistent with Zigarmi et al.'s study which found that workload balance can affect organizational behavior such as organizational commitment [43]. Furthermore, task variety is also related to organizational commitment [44].

Finally, individual factors consist of connectedness with colleagues, connectedness with leader, collaboration and feedback [22]. Ansari et al. in their study reported that fairness in relationship among employees was associated with all components of organizational commitment [45]. Starnes, Truhon and McCarthy also mentioned that connectedness with colleagues and leaders contributed positively towards organizational commitment [46]. Besides that, feedback from leader or supervisor is important to reduce role and performance ambiguity among workers, and enable them to improve their own weaknesses and work performance which indirectly fulfills the expectations by the leader or supervisor [47]. A study by Veeriah, Piaw and $\mathrm{Li}$ on the other hand found that teacher collaboration was significantly correlated with organizational commitment [48].

\section{B. The Role of Work Intention as \\ Mediator}

Intention has been shown to be a strong construct in the attitude-intention-behavior sequence [23]. Zigarmi et al. stated that work intention needs to be measured as a mediator because intentions are far better predictors of resultant behaviors as compared to outcome of organizational commitment or job satisfaction [23]. Furthermore, work intention is divided into five intentions including intent to stay, intent to use organizational citizenship behavior, intent to perform, intent to use discretionary effort, and intent to endorse.

Zigarmi et al. stated that intent to stay is defined as the extent an employee intends to remain with the organization [23]. They found that intent to stay was correlated with other important outcome variables such as organizational commitment and job satisfaction. On the other hand, autonomy, feedback, distributive justice and connectedness with leader were also correlated with work intention. Besides that, intent to use OCBs also showed strong correlation with outcome variables such as job satisfaction, organizational commitment and performance [23, $49,50,51]$. This intention was also correlated with antecedent variables such as procedural justice, distributive justice, connectedness with leader and meaningful work $[23,52,53]$. Intent to use discretionary effort as mentioned by Zigarmi et al. has positive correlation with antecedents of positive colleague relationships and employee-manager relationships [23, 54, 55], and finally has shown positive correlation with psychological contract fulfillment, and affective commitment to the job and organization [56]. Next, intent to endorse was found to have positive correlation with organizational commitment, OCBs, trust in the organization and in-role performance [57], and also significant correlation with procedural justice [58]. Zigarmi et al. stated that intent to perform has shown that employees intend to do their jobs at a higher level thereby effectively helps organizational success [23].

A study conducted by Nasyira, Othman and Ghazali found that support from supervisor has a positive correlation with intent to stay [59]. Perryer et al. also stated that employees become more committed and intend to stay with the organization when they feel that the organization responds actively towards them [60].

\section{RESEARCH OBJECTIVES}

Based on the literature reviews discussed, the objectives of this study was to:

1. examine the direct effect of employee work passion and its' dimensions (organizational, job and individual factors) on organizational commitment.

2. examine the direct effect of employee work passion and its' dimensions (organizational, job and individual factors) on work intention.

3. examine the direct effect of work intention on organizational commitment.

4. test the role of work intention as a mediatior in the relationship between organizational, job and individual factors on organizational commitment.

\section{METHODOLOGY}

This study employed a cross-sectional survey design to achieve the objectives. Data were collected using questionnaires distributed to respondents. According to Idris, a cross-sectional study is used to collect information from predetermined population samples at one point in time [61].

\section{A. Respondents}

The questionnaires were distributed to 400 teachers in Selangor, one state in Malaysia. However, only 355 questionnaires were accepted as complete to be used in data analysis. The selection of teachers as a sample of the study was in line with the study conducted by Shaari, Romle and Kerya who found that apart from performing routine academic tasks, teachers were also faced with responsibilities of nonacademic tasks daily, such as doing clerical work, co-curriculum activities and providing school activity reports [62]. Teachers were selected through multi-stage cluster random sampling method. According to Yahaya et al., cluster sampling is convenient because each sample unit is a set or individual group [63]. Creswell states that to identify the 
sampling technique for a population is to use a single stage or multiple stage sampling (called clustering) [64]. In a single-stage sampling technique, researchers choose populations and directly make the individuals within the population as respondents of the study [64]. For multi-stage random sampling technique, Creswell states that the researcher identifies a group (group or organization), get the individual names within the group, and select respondents among them [64]. This study also used Structural Equation Model (SEM) for data analysis. According to Sousan, a total sample size should be balanced depending on the analysis method [65]. Kline said that the most suitable sample size is 200 respondents, while Hair et al. suggest that the minimum sample size of 100 to 150 people is the most appropriate number to use for SEM [66, 67].

\section{B. Research Instruments}

In this study, work passion was measured using an inventory developed by Nimon and Zigarmi which is known as Work Cognition Inventory [22]. This inventory contains three dimensions, which is organizational, job and individual factors, where each dimension consists four subconstructs. Each subconstruct contains 12 items with a total of 36 items using a 6-point likert scale. The reliability of this inventory showed high reliability with the value of Cronbach alpha coefficient is more than 0.80 [22].

This study also used the inventory developed by Zigarmi et al. which is the Work Intention Inventory to measure work intention [23]. This inventory contains five subscales consisting of intent to remain, intent for discretionary effort, intent to endorse, intent to perform and intent to use organizational citizenship behaviors (OCBs). Each subscale contains five items with a total of 25 items using a 6-point likert scale. Reliability of Work Intention Inventory developed by Zigarmi et al. on 261 communications sector employees showed a high alpha Cronbach which is more than 0.80 [23].

Finally, this study also used the ThreeComponent Organizational Commitment Questionnaire developed by Allen and Meyer [13]. This questionnaire contains three components consisting of affective commitment, continuance commitment and normative commitment. Each component contains eight items with a total of 18 items using a 7-point likert scale. The reliability of this questionnaire showed the alpha Cronbach is more than 0.70 for affective and continuance commitment, however, the alpha Cronbach for normative commitment is 0.59 [13].

\section{Data Analysis}

Data were analyzed using descriptive analysis to explain the frequency, mean, and the level for work passion factors, work intention and organizational commitment. Inferential statistics were analyzed using Structural Equation Modelling

(SEM). Hair et al. stated that SEM is a technique that allows separate relationships for each set of dependent variables [67]. It provides the appropriate and most efficient estimation technique for a series of separate multiple regression equations estimated simultaneously [67]. Hair et al. characterized it by two basic components: (1) the measurement model and (2) the structural model [67]. The structural model is the path model, which relates independent to dependent variables. However, measurement model enables researcher to use several variables (indicators) for a single independent or dependent variable. In this study, the researcher first conducted a confirmatory factor analysis (CFA) as data preparing of measurement model [67]. Then only the structural model was analyzed to test the objectives of this study.

The guidelines for a good model fit is obtained in which convergent validity needs to be considered in the measurement model and structural model [67]. Convergent validity indicators include factor loadings should be at least 0.50 and ideally 0.70 or higher; Average Variance Extracted (AVE) should be 0.50 or higher; and construct reliability should be 0.70 or higher. However, reliability between 0.60 and 0.70 may be accepted. Finally, there are several Fitness Indices that reflect how fit is the model to the data at hand which include Chi square/df, Goodness-of-Fit Index (GFI), Comparative Fit Index (CFI), Tucker Lewis Index (TLI) and Root Mean Square Error of Approximation (RMSEA). These indices follow the recommended indices by Hair et al. [67].

\section{RESULTS}

A. Descriptive Analysis

This analysis was conducted to determine the level of work passion, work intention and organizational commitment among teachers. The levels were determined by the mean of each variable using interval calculation suggested by Schweigert [68]. Results showed that the level of work passion and organizational commitment among teachers were at moderate levels, however, teachers showed a high level of work intention. The results are presented in Table 1

Table 1. Level of work passion, work intention and organizational commitment

\begin{tabular}{lccc}
\hline \multicolumn{1}{c}{ Variables } & Mean & $\begin{array}{c}\text { Standard } \\
\text { Deviation }\end{array}$ & Level \\
\hline Work passion & 4.29 & 0.66 & Moderate \\
Work intention & 4.45 & 0.66 & High \\
Organizational & 4.69 & 0.91 & Moderate \\
Commitment & & & \\
\hline
\end{tabular}




\section{B. Results of Confirmatory Factor Analysis (CFA)}

Individual constructs of work passion, work intention and organizational commitment in this study were then analyzed using confirmatory factor analysis to evaluate the construct validity. The measurement model for work passion included 36 items. However, the model did not achieve a good-fit model. Therefore, it was respecified using recommendation from modification indices and by examining items with low loadings. The respecified measurement model for work passion with 10 items finally achieved a good fit with all values meeting the recommended values as suggested by Hair et al. [67] and Awang [69].

The measurement model for work intention was initially analyzed using 25 items. Based on the results of poor fit, this model was also respecified by using recommendation from modification indices and by examining items with low loadings. Hence, the respecified model of work intention with 15 achieved a good fit with all values meeting the recommended values as suggested by Hair et al. [67] and Awang [69].

Finally, the measurement model of organizational commitment was analyzed using 18 items. The results of CFA also showed a poor fit between the model and the data. This measurement model was respecified, thus the respecified model of work intention with 8 items achieved a good fit with all values meeting the recommended values as suggested by Hair et al. [67] and Awang [69]. However, the dimension of continuance commitment was eliminated due low factor loadings leaving this model with only two dimensions namely affective and normative commitment. Table 2 presents the fitness indices, values achieved for level of acceptance and convergent validity of each construct in this study.

Table 2. The fitness index, value achieved for level of acceptance and convergent validity of each construct

\begin{tabular}{|c|c|c|c|c|c|}
\hline Constructs & Level of Acceptance & $\begin{array}{c}\text { Number of Item } \\
\text { (Accepted) }\end{array}$ & $\begin{array}{c}\text { Value of Factor } \\
\text { Loading }\end{array}$ & AVE & $\mathbf{C R}$ \\
\hline Work passion & $\begin{array}{l}\text { Chisq } / \mathrm{df}=1.86 \\
\mathrm{GFI}=0.97 \\
\mathrm{CFI}=0.99 \\
\mathrm{TLI}=0.98 \\
\mathrm{RMSEA}=0.05\end{array}$ & 10 items & 0.60 to 0.90 & 0.59 & 0.93 \\
\hline Work intention & $\begin{array}{l}\text { Chisq/df }=2.71 \\
\text { GFI }=0.92 \\
\text { CFI }=0.96 \\
\text { TLI }=0.95 \\
\text { RMSEA }=0.07\end{array}$ & 15 items & 0.60 to 0.90 & 0.67 & 0.97 \\
\hline Organizational Commitment & $\begin{array}{l}\text { Chisq/df }=2.39 \\
\text { GFI }=0.97 \\
\text { CFI }=0.98 \\
\text { TLI }=0.97 \\
\text { RMSEA }=0.06\end{array}$ & 8 items & 0.51 to 0.56 & 0.54 & 0.90 \\
\hline
\end{tabular}

\section{Results of Structural Equation Modeling}

The structural model consists of the direct paths of work passion with its dimensions (organizational, job and individual factors) towards work intention and organizational commitment. The results showed that the structural model has a good fit RMSEA $=0.08, \mathrm{GFI}=0.95$, $\mathrm{CFI}=0.97, \mathrm{TLI}=0.95$, and Relative Chi-square $($ Chisq/df) $=3.30$. However, there were several paths showing no significant effect. Therefore, the model was respecified by eliminating these non-significant paths as suggested by Hair et al. [67] and Awang [69]. The results of the respecified structural model showed a better fit with the data with RMSEA $=0.08$, GFI $=0.95$, CFI $=0.97$, TLI $=0.95$, and Relative Chi-square (Chisq/df) $=3.22$, with significant paths. The results are shown in Fig 1.

Based on respesified structural model (Fig 1), results of each path were used to answer the objectives. The first objective of this research was to determine the effect of work passion and its' dimensions (organizational, job and individual factors) on organizational commitment among teachers.
Results showed that job factors have a significant direct effect on organizational commitment among teachers $(\beta=$ $.18, \mathrm{p}<.05)$, meanwhile organizational factors and individual factors did not have significant direct effects on organizational commitment. These results concluded that based on the three work passion factors, only job factors have a significant direct effect on organizational commitment.

The second objective was to test the direct effect of work passion and its' dimensions (organizational, job and individual factors) on work intention. Results in Table 3 showed that there were significant direct effects of organizational factors on work intention $(\beta=.30, p<.05)$, job factors on work intention $(\beta=.16, p<.05)$, and individual factors on work intention $(\beta=.37, \mathrm{p}<.05)$.

The third objective was to test the direct effect of work intention on organizational commitment. Results showed that there was significant direct effect of work intention on organizational commitment $(\beta=.70, \mathrm{p}<.05)$. The results are shown in Table 3.

Table 3. Results of work passion on work intention and organizational commitment 


\begin{tabular}{|c|c|c|c|c|}
\hline No & Objectives & $\mathbf{R}^{2}$ & $\boldsymbol{\beta}$ & Results \\
\hline \multirow[t]{4}{*}{1} & $\begin{array}{l}\text { Examine direct effect of employee work passion and its' dimensions } \\
\text { (organizational, job and individual factors) on organizational commitment. }\end{array}$ & 0.67 & & \\
\hline & - Organizational factor & & ns & Reject \\
\hline & Job factor & & $0.18^{*}$ & Accept \\
\hline & Individual factor & & Ns & Reject \\
\hline \multirow[t]{4}{*}{2} & $\begin{array}{l}\text { Examine the direct effect of employee work passion and its' dimensions } \\
\text { (organizational, job and individual factors) on work intention. }\end{array}$ & .57 & & \\
\hline & - $\quad$ Organizational factor & & $0.30^{*}$ & Accept \\
\hline & Job factor & & $0.16^{*}$ & Accept \\
\hline & Individual factor & & $0.37 *$ & Accept \\
\hline 3 & Examine the direct effect of work intention on organizational commitment. & & $0.70^{*}$ & Accept \\
\hline
\end{tabular}

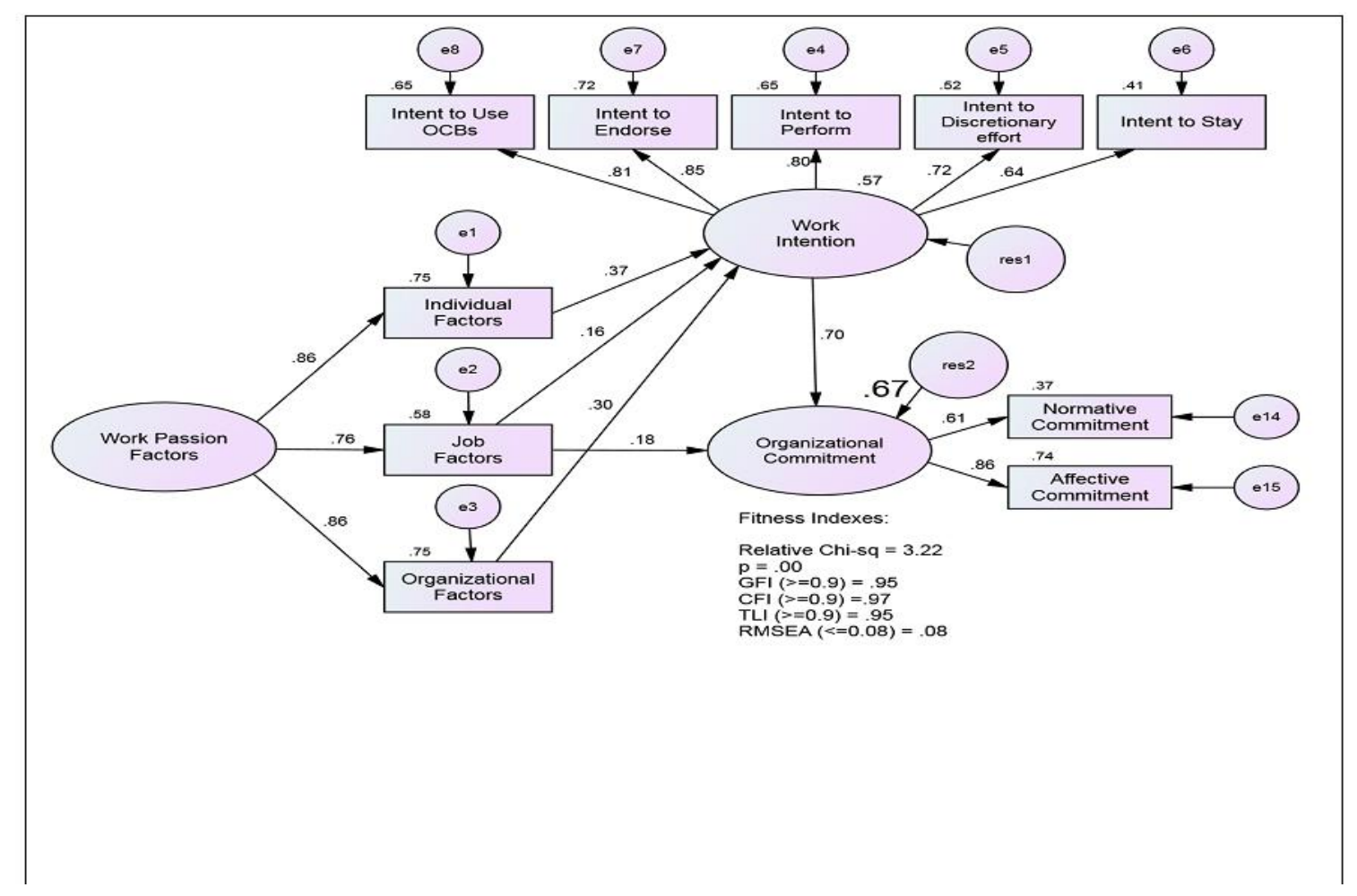

Fig 1. Results of the respecified structural model

The fourth objective of this study was to determine the role of work intention as a mediator in the indirect effect of work passion factors on organizational commitment. According to Hair et al. [67], the mediator effect can be calculated by indirect effect calculation, in which path $\mathrm{A} x$ path $\mathrm{B}$ is more than 0.08 , meaning that values 0.08 and above have a mediation effect. Path A refers to the values of independent variable to mediator variable, and path $B$ refers to the values of mediator variable to dependent variable. The results reported in Table 4 showed that objective 4 was accepted in which work intention has a mediating effect on organizational factors and organizational commitment $(\beta=$ $0.26)$, job factors on organizational commitment $(\beta=0.11)$, and individual factors on organizational commitment $(\beta=$ $0.21)$. The results concluded that objective 4 was accepted in this study.

Table 4. Hypothesis testing the work intention has a mediating role in the indirect effect of work passion factors on organizational commitment 


\begin{tabular}{lll}
\hline Objective & $\begin{array}{l}\text { Indirect effect } \\
\text { calculation }> \\
\text { 0.08 }\end{array}$ & $\begin{array}{c}\text { Result } \\
\text { S }\end{array}$ \\
\hline $\begin{array}{l}\text { Test the role of work intention as a mediatior in the relationship between } \\
\text { organizational, job and individual factors on organizational commitment. }\end{array}$ & & \\
- $\quad$ Organizational factor & $0.37 \times 0.70=0.26$ & Accept \\
- Job factor & $0.16 \times 0.70=0.11$ & Accept \\
- Individual factor & $0.30 \times 0.70=0.21$ & Accept \\
\hline
\end{tabular}

\section{DISCUSSION}

Organizational commitment among employees is important to determine organizational effectiveness as employees with higher organizational commitment have higher motivation to stay with their organization. This study was conducted to determine whether work passion factors can affect work intention and organizational commitment among teachers. However, results showed only one dimension of work passion was significantly related with organizational commitment which was job factors. Job factors in this study consisted of autonomy, workload balance and task variety. These job factors are needed to sustain and improve organizational commitment among teachers. The result of this study was supported with Huang and Hsiao [39] and Liu and Norcio [40] in which they stated that job factor is a strong predictor towards affective commitment. Furthermore, Lee and Ashforth also stated that emotional, high workload, lack of autonomy and intent to turnover may decrease organizational commitment among employees [41]. In this study, teachers agreed that workload balance in the job factor should be considered. Together with autonomy and task variety, it can contribute towards organizational commitment specifically towards affective commitment and normative commitment.

This study also reported an interesting result, in which work intention mediated the indirect effect of work passion factors on organizational commitment. Zigarmi et al. stated that intention can be strong a construct in the attitudeintention-behavior sequence [23]. It is proved by several models such as the theory of reasoned action [24] and the theory of planned behavior [25, 26] which explain the relationship between intention and behavior, and also the role of intention in predicting behavior [27]. This study showed that work intention can be a good predictor and mediator towards organizational commitment. Besides that, intention precedes any behavior and it is a precursor in performing attitude-behavior. Data in this study showed that work intention is important not only for organization but also to teachers themselves. When teachers have the intention, they will put effort and commit to organization with full sincerity. In addition, this study proved that work passion factors including organizational factors, individual factors and job factors require work intention in determining organizational commitment.

The findings of this study concluded that work passion, work intention and organizational commitment needed to be emphasized in every school teacher, especially with the results of the structural model showing that $67 \%$ of organizational factors, individual factors and job factors together with work intention were high contributors towards organizational commitment among teachers. Thus, by improving work intention, this might help increase the level of organizational commitment among teachers.
Organizations as well schools need to play a good role in supporting teachers, considering the workload and responsibilities of teachers in educating the young generation.

\section{CONCLUSION}

There are two implications of this study. Theoretically, this study can contribute towards understanding better the theory of planned behavior [25, 26] among teachers as the structural model of this study supported the theory of planned behavior. Practically, this study can educate teachers and create awareness among employees on the importance of having work passion and work intention in enhancing organizational commitment.

This study was limited to primary and secondary teachers in one state in Malaysia. Therefore, the findings have limitations in its ability to be generalized across other professions as the experiences of work passion, work intention and organizational commitment may differ. Apart from that, future research is suggested to expand various characteristics of the respondents, and to test the work passion factor and work intention among employees by using other research designs such as longitudinal or qualitative design to get richer and in-depth information about work passion, work intention and organizational commitment.

\section{REFERENCES}

1. Minister of Education Malaysia. (2015). Malaysian Education Development Program 2013-2025. (Pelan Pembangunan Pendidikan Malaysia 2013-2025). Available: https://www.moe.gov.my/index.php/my/arkib/dasar/laporan-tahunan$\underline{2015}$

2. Affendi, F. (2014). Level of job satisfaction and organizational commitment among vocational college teachers: A structural equation modeling. (Tahap kepuasan kerja dan komitmen organisasi dalam kalangan guru kolej vokasional: Pendekatan structural equation model.) UTHM, Unpublished Master's Project.

3. Rabindarang, S. (2012). Relationship of distributive leadership towards organizational commitment and job stress in vocational and technical education. (Hubungan kepemimpinan distributif terhadap komitmen: Organisasi dan tekanan kerja dalam pendidikan teknik dan vokasional.) UPSI, Unpublished Doctoral Thesis.

4. Ibrahim, A, Halim, F. W, \& Wan Sulaiman, W. S. W. (2017) Factors influencing organizational commitment among school teachers. (Faktor-faktor yang mempengaruhi komitmen organisasi dalam kalangan guru sekolah). International Research Journal of Education and Sciences, 1(1), 51-54.

5. Bajunid, I. A. (1995). Practices and challenges of education management in Malaysia: A critical review. (Amalan dan cabaran pengurusan pendidikan di malaysia: satu tinjauan kritikal). Jurnal Pengurusan Pendidikan, 5(1), 113.

6. NUTP. (2009). Many teachers experience mental health. (Ramai guru sakit jiwa). In Kosmo 
newspaper, Siti Nor Afzan Kasiman. Available: http://ww1.kosmo.com.my/kosmo/content.asp?y=2009

7. Polly, D., Mims, C., Shepherd, C. E., \& Inan, F. (2010). Evidence of impact: Transforming teacher education with preparing tomorrow's teachers to teach with technology (PT3) grants. Teaching and Teacher Education, 26, 863-870.

8. Halim, F. W. (2003). Personality and its' correlates with job stress and work life balance among teachers. (Personaliti serta hubungannya dengan tekanan kerja dan kehidupan bekerja di kalangan guru). Jurnal Psikologi Malaysia, 17, 65-83.

9. Halim, R. A. (2009). An exploratory study of distributed leadership in Malaysia. (Kajian eksplorasi distributed leadership di Malaysia). Seminar Nasional Pengurusan dan Kepemimpinan Pendidikan ke-16, Institut Aminuddin Baki.

10. Abdullah, M. K., Sekong, M., \& Laji, H. (2017). Emotional intelligence and teachers' commitment towards organization. (Kecerdasan emosi dan komitmen guru terhadap organisasi). Jurnal Psikologi dan Kesihatan Sosial, $142-52$.

11. Dee, J. R., Henkin, A. B. \& Singleton. C. A. (2006). Organizational commitment of teachers in urban schools: Examining the effects of team structures. Urban Education, 41, 603-27.

12. Allen, N. J., \& Meyer, J. P. (1996). Affective, continuance, and normative commitment to the organization: An examination of construct validity. Journal of Vocational Behavior, 49(3), 252-276. http://dx.doi.org/10.1006/jvbe.1996.0043

13. Meyer, J. P., \& Allen, N. J. (1991). A three-component conceptualization of organizational commitment. Human Resource Management Review, 1, 61-89.

14. Nguni, S., Sleegers, P., \& Denessen, E. (2006). Transformational and transactional leadership effects on teachers' job satisfaction, organizational commitment, and organizational citizenship behavior in primary schools: The Tanzanian case. School Effectiveness and School Improvement, 17(2), 145-177.

15. Louis, K. S. (1998). Effects of teacher quality of work life in secondary schools on commitment and sense of efficacy. School Effectiveness and School Improvement, 9, 1-27.

16. Singh, K. \& Billingsley, B. S. (1998). Professional support and its effects on teachers' commitment. Journal of Educational Research, 91(4), 229-239.

17. Porter, L. W., Steers, R. M., Mowday, R. T., \& Boulian, P. V. (1974). Organizational commitment, job satisfaction and turnover among psychiatric technicians. Journal of Applied Psychology, 59(5), 603-609.

18. Gangai, K. N. \& Agrawal, R. (2015). Job satisfaction and organizational commitment: Is it important for employee performance? International Journal Management Business Research, 5(4), 269-278.

19. Zigarmi, D. \& Nimon, K. (2011). A cognitive approach to work intention: The stuff that employee work passion is made of? Advances in Developing Human Resources, 13(4), 447-461.

20. Perrewé, P. L., Hochwarter, W. A., Ferris, G. R., Mcallister, C. P., \& Harris, J. N. (2014). Developing a passion for work passion: Future directions on an emerging construct. Journal of Organizational Behavior, 35(1), 145-150.

21. Vallerand, R. J., Mageau, G. A., Blanchard, C. M. \& Koestner, R. (2003). Les passions de l'ame: on obsessive and harmonious passion. Journal of Personality and Social Psychology, 85, 756-767.

22. Nimon, K. \& Zigarmi, D. (2014). The work cognition inventory: Initial evidence of construct validity for the revised form. Journal of Career Assessment, 23(1), 117-136.

23. Zigarmi, D., Nimon, K., Houston, D., Witt, D. \& Diehl, J. (2012). The of Business Administration Research, 1(1), 24-42. doi 10.5430/jbar.v1n1p24.

24. Fishbein, M. \& Ajzen, I. (1975). Belief, attitude, intention and behavior: An introduction to theory and research. Boston: AddisonWesley.

25. Ajzen, I. (1985). From intentions to action: A theory of planned behavior. In Kuhl, J. and Beckman, J. (Eds), Action control: From cognitions to behaviors. New York: Springer

26. Ajzen, I. (1991). The theory of planned behavior. Organizational Behavior and Human Decision Processes, 50, 179-211.

27. Webb, T. L., \& Sheeran, P. (2006). Does changing behavioral intentions engender behavioral change? A meta-analysis of the experimental evidence. Psychological Bulletin, 132, 249-268. doi:101037/0033-2909.132.2.249

28. Ajzen, I., \& Fishbein, M. (1980). Understanding attitudes and predicting social behavior. Englewood Cliffs, NJ: Prentice-Hall.

29. Tremblay, M., Cloutier, J., Simard, G., Chenevert, D., Vandenberghe, C. (2010). The role of HRM practices, procedural justice, work intention inventory: Initial evidence of construct validity. Journal

organizational support and trust in organizational commitment and inrole and extra-role performance. International Journal of Human Resource Management, 21, 405-433.

30. Haar, J. M., Spell, C. \& O'Driscoll, M. (2009). Managing work-family conflict: Exploring individual and organizational options. New Zealand Journal of Human Resources Management, 9(3), 200-215.

31. Rahman, Navid Shahzad, Kiran Mustafa, Muhammad Fayaz Khan \& Faizan Qurashi. (2016). Effects of organizational justice on organizational commitment. International Journal of Economics and Financial Issues, 6(S3), 188-196.

32. Daud, K. A. K. (2014). The impact of slow career growth on organizational commitment and job satisfaction: A study of a "closed" government agency in Malaysia. RMIT Universitiy: $\mathrm{PhD}$ Thesis.

33. Weng, Q., McElroy, J. C., Morrow, P. C., \& Liu, R. (2010). The relationship between career growth and organizational commitment. Journal of Vocational Behavior, 77, 391-400. 10.1016/j.jvb.2010.05.003

34. Barbier, M., Hansez, I., Chmiel, N., \& Demerouti, E. (2012). Performance expectations, personal resources, and job resources: How do they predict work engagement. European Journal of Work and Organizational Psychology, https://doi.org/10.1080/1359432X.2012.704675

35. Wrzesniewski, A., McCauley, C., Rozin, P., \& Schwartz, B. (1997). Jobs, careers, and callings: People's relations to their work. Journal of Research in Personality, 31(1), 21-33. http://dx.doi.org/10.1006/jrpe.1997.2162

36. Geldenhuys, M., Laba, K. \& Venter, C. M. (2014). Meaningful work, work engagement and organizational commitment. SA Journal of $\begin{array}{lll}\text { Industrial } & \text { Psychology, } & \text { 40(1), }\end{array}$ doi: https://doi.org/10.4102/sajip.v40i1.1098

37. Ozturk, F. (2010). Determinants of organizational citizenship behavior among knowledge workers: The role of job characteristics, job satisfaction, and organizational commitment. Middle East technical university, Turkey: Master Thesis

38. Eby, L. C., Freeman, D. M., Rush, M. C., \& Lance, C. E. (1999). Motivational basis of affective organizational commitment: A partial test of an integrative theoretical model. Journal of Occupational and Organizational Psychology, 72, 463-483.

39. Huang, T. \& Hsiao, W. (2007). The causal relationship between job satisfaction and organizational commitment. Social Behavior and Personality: An international Journal, 35, 1265-1276.

40. Liu, S. \& Norcio, R. (2008). Mediating effects of job characteristics on job satisfaction and organizational commitment of Taiwanese expatriates working in Mainland China. The Business Review, 9, 62-69.

41. Lee, R. T., \& Ashforth, B. E. (1996). A meta-analytic examination of the correlates of the three dimensions of job burnout. Journal of Applied Psychology, 81, 123-133.

42. Dewe, P. J. (1992). Applying the concept of appraisal to work stressors: Some exploratory analysis. Human Relations, 45, 143-64.

43. Zigarmi, D., Nimon, K. \& Shuck, B. (2014). Employee engagement: Job attitude or mediator between job attitude and affect. Proceedings of the Academy of Human Resource Development Conference.

44. Brown, S. P. (1996). A meta-analysis and review of organizational research on job involvement. Psychological Bulletin, 120, 235-255. doi:10.1037/0033-2909.120.2.235

45. Ansari, M. A., Hung, D. K. M. \& Aafaqi, R. (2007). Leader-member exchange and attitudinal outcomes: Role of procedural justice climate. Leadership \& Organization Development Journal, 28(8), 690-709.

46. Starnes, B. J., Truhon, S. A., \& McCarthy, V. (2005). Organizational trust: Employee-employer relationships. The Human Development and Leadership Division, 6-8, www.asq.org/hd

47. Agho, A. O., Mueller, C. W., \& Price, J. L. (1993). Determinants of employee job satisfaction: An empirical test of a causal model. Human Relations, 46(8), 1007-1027. doi: 10.1177/001872679304600806.

48. Veeriah, J., Piaw, C. Y., \& Li, S. Y. (2017). The impact of school culture on teachers' organizational commitment in primary cluster schools in Selangor. Educational Leader, 5, 1-18.

49. LePine, J. A., Johnson, D. E. \& Erez, A. (2002). The nature and dimensionality of organizational citizenship behavior: A critical review and meta-analysis. Journal of Applied Psychology, 87(1), 52-65.

50. Organ, D. W. \& Ryan, K. (1995). A meta-analytic review of attitudinal and dispositional predictors of organizational citizenship behavior. Personnel Psychology, 48, 775802. 


\section{AUTHORS PROFILE}

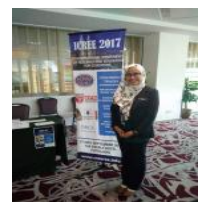

Amalina Ibrahim Amalina Ibrahim possesses Doctor of Philosophy in Psychology from Universiti Kebangsaan Malaysia, under supervision Assoc. Prof. Dr. Wan Shahrazad Wan Sulaiman and Dr. Fatimah wati Halim. Her research interests are including work passion factors, work intention, organizational commitment and organizational citizenship behavior (OCB) among teachers, also, motivation, passion for learning and selfregulated learning among university students.

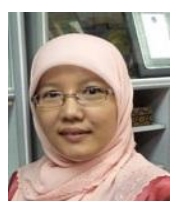

Wan Shahrazad Wan Sulaiman Dr. Wan Shahrazad Wan Sulaiman is an associate professor at Center of Human and Societal Well-Being, Faculty of Social Sciences and Humanities, Universiti Kebangsaan Malaysia, Malaysia. She received her Doctor of Philosophy in Psychology from International Islamic University Malaysia. Her field of specialization is psychometrics. Among her research interests are application of psychological tests, adaptation and standardization of psychological tests among prisoners for parole evaluation, psychological profile of drug addicts, personality profile of adolescents and juvenile delinquents, and assessment of critical thinking ability among university students. She has published her works in Journal Psychology Malaysia, Akademika, Pertanika Journal of Social Sciences and Humanities, World Applied Sciences Journal, American Journal of Applied Science and several other journals.

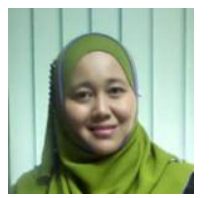

Fatimah wati Halim is a senior lecturer at Center of Human and Societal Well-Being, Faculty of Social Sciences and Humanities, Universiti Kebangsaan Malaysia, Malaysia. She received her Doctor of Philosophy in Psychology from Universiti Kebangsaan Malaysia. Her field of specialization is in industrial and organizational psychology. Among her research interests are personnel psychology (tests, measurement and psychological assessment especially personality testing in personnel, competency and performance management, personality and organizational behavior especially leadership, motivation and self-efficacy. She has published her works in Journal Psychology Malaysia, Akademika, Pertanika Journal of Social Sciences and Humanities, World Applied Sciences Journal, and several other journals 